\title{
System of gender attitudes of the poetic system of anna akhmatova
}

\author{
Gudzina Victoria Anatolyevna \\ Senior Lecturer of \\ Russian Language and Literature department \\ Bukhara State University \\ Gudzina.V.A.17@gmail.com
}

\begin{abstract}
As you know, the study of the female worldview and the female experience of living life allows you to look deep into the creative laboratory of the poetess, see the system of correlations and ratios of the female and male in her lyrics and trace the extent to which the nature of this interaction has formed the system of Akhmatova's gender attitudes.
\end{abstract}

Key words: female worldview, gender attitudes, poetic system, lyrics, creative behavior, symbolism, masculine.

\section{I.Introduction}

In the work of Russian poetesses of the 20th century, two main trends can be distinguished within the framework of which it develops: these are attempts to either imitate male poetry, or to illuminate precisely a special, female view of the problems typical of lyrics. This means that there are two poles - imitation of men and demonstration of female individuality. The first can undoubtedly include Marina Tsvetaeva, who even referred to herself as a poet and in no case a poetess. Anna Akhmatova is in constant maneuvering between these two poles, so it is not possible to unambiguously assign her to one of them.

\section{II.Literature review}

The first model of creative behavior is the copying of the "masculine" syllable. Akhmatova embodies influential literary movements in her work, such as symbolism and, in some aspects, acmeism, which were essentially largely hostile, both in theory and often in reality, to women poets. Members of these movements developed images and promoted manifestos that often precluded the participation of an active female figure. But Akhmatova achieved exactly this, borrowing images from these movements and rethinking them in such a way as to strengthen her authority as a poet.

I.G. Ehrenburg, as a contemporary of Akhmatova, admired her first books and spoke positively about the poetry's lyrics in the article "Notes on Russian Poetry", published in France: "Akhmatova, describing the soul of a modern woman, does not resort to the cliches of some" decadent "poetess like Vilkina, nor to comparisons of women with "witch drinks" and the like, but comes from what we see every day, revealing a woman's soul behind the shell "[12, 16].

\section{III.Analysis}

Some of her poems are characterized by a certain "masculine", pronounced dominant attitude towards the object of love:

Sun in the sky. The sun shines brightly

Go to the wave to whisper about pain. 
Oh, she'll probably answer.

And maybe she will kiss ("The smell of blue grapes is sweet").

[Солнце в небе. Солнце ярко светит

Уходи к волне про боль шептать.

О, она, наверное, ответит.

А быть может, будет целовать («Сладок запах синих виноградин»)]

A negative stereotype has developed among the Symbolists and Acmeists about traditionally female poetry, glorifying nature and relationships. Osip Mandelstam, in particular, wrote: "Girls and young ladies, needlewomen of poetry, those who willingly call themselves Miami and keep a reverent memory of the great poet's indulgent caress. Your business is easier, you write poetry to please. And we will do this: - a conspiracy of Russian youth - not to look at the young ladies who write poetry " $[6,216]$.

O. Mandelstam, perhaps, ultimately accepted A. Akhmatova as a poet of equal merit. However, his commentary reflects a point of view that was prevalent among the Russian literary elite.

Akhmatova was sensitive to the fact that she was portrayed simply as a "lady poet". When she was eleven years old, her father "for some reason" called her a "decadent poetess." She also described "Evening", her first collection, with uncharacteristic modesty: "For some reason, these poor poems of an empty girl are reprinted for the thirteenth time" [2, 245].

That is, on the one hand, Akhmatova was confident in her chosenness and exclusivity. On the other hand, she was tormented by internal dissatisfaction, perhaps secretly she considered herself really unworthy of the purely "male" mission of the prophet. This negative attitude to the "female share" and to the emotions traditionally attributed to women breaks through in many of her poems, for example, in the poem "He loved ...": "He loved three things in the world: / During the evening singing, white peacocks / And erased maps of America. / Didn't like when children cry, / Didn't like tea with raspberries / And female hysteria. / ... And I was his wife."

For Akhmatova, taking into account her attitude to her mission, the main thing was to stake out a place in the male world of poets.

Akhmatova grew into a poet of Russia, since she carried her era in herself, and then she was called that: "Epoch". From the point of view of well-being, or at least a minimal, everyday "device", the life of Anna Akhmatova is a living hell. In July 1922, Akhmatova wrote a poem, where she expressed not only her attitude towards Russia, towards her fate, but, as it were, revealed a part of her soul: Not with those who threw the earth / To be torn apart by enemies. / I will not heed their rude flattery, / I won't give them my songs.

In the last two lines - all of Akhmatova: restrained, majestic, simple. She prepared to carry her cross, drink her cup. A cup of unthinkable loneliness, because she was never "with either one or the other." Her life was crumbling. And then she, the poet Anna Akhmatova, will take the brunt of what is happening in the country on her shoulders. The Soviet regime, terror and repressions that reigned in the country, systematically finished off Akhmatova. In 1939, her son was arrested, and this tragedy made Akhmatova a great poet of Russia.

In the 1940s-1960s, the poem Requiem was written, opening with a prosaic preface that resembles a newspaper article and introduces us to the atmosphere of that era.

The poet is not recognized, but "recognized", the woman's lips are "blue" from the cold and worries, those around her speak in a whisper and "in the ear." A woman from the prison line asks 
Akhmatova to describe it, hopes for the triumph of justice. And the poetess does her duty, writes about her friends in misfortune and about herself:

No, and not under an alien firmament,

And not under the protection of alien wings,

- I was then with my people,

Where my people, unfortunately, were.

Нет, и не под чуждым небосводом,

И не под зашитой чуждых крыл, -

Я была тогда с моим народом,

Там, где мой народ, к несчастью, был.

In the article "Akhmatova and Music" T.V. Tsivyan writes: "Akhmatova herself is still the best critic and commentator of her works, and almost everything that her researchers come to now turns out to be already written by her either in a poetic text or in prose, sketches, etc. Strictly speaking, the task of researchers is not so much to explain as to look in Akhmatova's texts for what is explained to her "[10, 195].

The "male" model of behavior, as a rule, is forcedly accepted by a woman in a critical situation. As you know, the 40s of the XX century became a difficult test for the Russian people, and circumstances demanded from Akhmatova not at all feminine behavior.

We know what's on the scales

And what is happening now.

The hour of courage has struck on our watch

And courage will not leave us.

Мы знаем, что ныне лежит на весах

И что совершается ныне.

Час мужества пробил на наших часах,

И мужество нас не покинет.

- writes Akhmatova during the Second World War, the same Akhmatova, who until recently "clasped her hands under a dark veil." Indeed, it sounds like a man, there is not even a trace of a woman's vision. The reason for this creative behavior is war - an event that canceled all gender differences and significantly advanced the process of equalizing the rights of men and women.

In general, it is clear that such a situation requires a woman not only to behave like a man, but to be ahead of men in some way - let us pay attention to how persistently Akhmatova repeats the word "courage" in the poem of the same name. We will not find such a concentration of masculinity in any work by a male poet.

A woman needs to defend her right, she needs to prove her ability to be courageous - this idea, among other things, the author tries to convey to us. This can be achieved not only through the subject matter, the system of images (war, blood, death, courage), but also through, for example, syntactic means and rhythm.

The heroine of Akhmatova always conceals a "masculine" confidence under female weakness, because she is a woman who is called upon to create and achieve success in this area.

The second model of creative behavior - the search for a woman's view of the main topics raised in the lyrics - turns out to be quite common and in many ways even more logical: who can reveal the 
inner world of a woman more deeply than herself? This idea fits well with the aesthetics of the Silver Age, when the first poetesses appeared. It should be noted that sophistication, somewhat artificial elegance, saloon character distinguishes the early lyrics of Akhmatova: The moon illuminates the cornices, / Wanders along the river ridge ... / Cold hands of the marquise / So fragrant, light. ("Masquerade in the Park").

The peculiarities of gender poetics are most clearly manifested in love lyrics. The Chinese researcher Zou Luwei points out that in her early lyrics, Akhmatova demonstrated a range of female emotional experiences that are born in most cases in connection with the tragedy of love feelings during a historical world revolution $[9,6]$.

Love in the mind of Akhmatova has a special value. The poet calls the fifth season of the year the season of love: That fifth season, / Only his praise. / Breathe the last freedom, / Because this is love. ("That Fifth Season of the Year"). She believes that autumn is the time of death for love: Between the maples there is an autumn whisper / He asked: "Die with me! ("Song of the last meeting").

Akhmatova, despite the demands to "expand" the scope of women's poetry, capturing new areas, deliberately and defiantly narrowed them down. And on this "span" of space, she showed all the possibilities of psychological fulfillment of the personality! Hence the uncertainty, unpredictability inherent in the internal state of Akhmatova's heroines [9, 3].

All feminine traits: an attentive gaze, a tremulous memory of cute things, grace and a touch of whims - are reflected in the early poems of Anna Akhmatova, and this gives them true lyricism.

The poetess sacrifices herself to love, Akhmatova dissolves in this feeling: Everything is for you: the daytime prayer, / And the painful heat of insomnia, / And my poems are a white flock, / And my eyes are blue fire. ("I don't know if you're alive or dead").

\section{IV.Discussion}

N.I. Artyukhovskaya points out that "Akhmatov's love, with all its high merits, is a closed process, independent of the world. Her conflicts do not intersect with the social conflicts of the century, but only come into contact with them with a common emotionally tense essence. The heroine Akhmatova spends her entire reserve of spiritual strength on the search for her "prince", a strong hero who can appreciate the beauty of her feelings" [1,23].

We see Akhmatova's innovation in the fact that the narrative becomes the meaning-generating constant of her lyric works.

I walked my friend to the front.

She stood in gold dust.

From the neighboring bell tower

Important sounds flowed.

The plot-plot organization of the lyric narrative in this poem is based on the principle of novelistic narration, which allowed V.M. Zhirmunsky in his time to correlate Akhmatov's poems with "poetic novellas": " $<\ldots>$ the moment of its development, whence opens up the opportunity to survey all the preceding course of facts "[3, 120].

Indeed, in a "poetic novella", it is not the incident itself that is the key event as in a prosaic novelistic statement, but serves as a pretext for "reviewing" the reasons for the development of a lyrical "explosion" of feelings, the essence of which can be revealed only in the unity of the elements that 
organize it - the lyric plot, the plot, and the narrative itself.

The peculiarity of A. Akhmatova's lyrics, as noted by literary scholars, is that the main distinctive features of Acmeist poetry - materiality, concreteness, tangibility of images, simplicity of language - form the original style of her work. A feature of her lyrics is becoming a "spoken verse", focused on colloquial speech - the speech is characteristically feminine, unlike, for example, contemporary poet Z. Gippius, who tended to speak on behalf of a man $[4,73]$.

The ideal of eternal femininity is extremely important in the poetic system of Akhmatova as a prominent representative of the Silver Age. Closer to the middle of the 20th century, the female vector of her poetry becomes simpler, since it pays attention not to the refinement of forms, but to the sincerity of feelings. The ideal of a woman striving for love as a moral value appears in the love lyrics of A.A. Akhmatova.

Particularly frequent is the theme of unrequited feelings, to which Anna Akhmatova's poem "How many requests from a beloved always" is dedicated. The general tendency turns out to be simple and understandable: the "female" vector of Akhmatova's poetry seeks to reveal themes familiar to the lyrics from a new point of view, which means, by new means (gravitation towards calmness, intimacy, sound writing that conveys softness and smoothness of speech, rather long phrases, musicality): $I$ learned to simply, live wisely, / Look at the sky and pray to God, / And wander long before the evening, / To tire unnecessary anxiety. ("I have learned to live simply, wisely").

The theme of love, especially unrequited love, is not only not new - since the time of the poetry of the troubadours it has been one of the main themes of the lyrics. However, one cannot but agree that the change from the lyric hero to the lyrical heroine in Akhmatov's poetry brings new colors to the old history.

In 1912 the collection of poems "Evening" was published. The name of the author: "Anna Akhmatova" is a pseudonym that Anna Gorenko took after her Tatar ancestor, Khan Akhmat; the name Anna was given to her in honor of her grandmother. This book of love lyrics was already harmonious and perfect; there was nothing childish in the verses; they belonged to the pen of a mature, mature poet, and even then were the true creations of Anna Akhmatova.

According to Boris Eikhenbaum: "there are no sharp changes in Akhmatova's work," since "she is very stable in her artistic method" $[11,16]$. Indeed, the two first collections of the poetess: Evening (1912) and Rosary (1914) are closely related. They present to the reader the intimate experiences of the female soul. Many critics regarded the early poems of the poetess as an intimate diary, as a confession, a confession. In our opinion, such an approach to the Evening and the Rosary has its own rationale: $I$ live like a cuckoo in a clock, / I do not envy birds in the forests. / They start and cook. / You know, such a share / Only to the enemy / I can wish.

As literary scholars L.S.Kislova and M.A.Vetoshkina justly write, analyzing the gender code of the poetess: "Flowers, a skirt, gloves, a veil, a feather on a hat and other details of a lady's wardrobe in A. Akhmatova's early poems are part of a certain cipher, language gestures and hints that create a female discourse in the poet's work, which in itself contradicts the harsh masculine poetry of Acmeism. Undoubtedly, A. Akhmatova's poems have an emphatically feminine nature, they seem to, willingly or unwillingly, violate the harmonious Acmeist system of values" [6, 224].

Akhmatova shows concrete human feelings, the concrete life of the soul, which experiences everything very strongly - languishes, rejoices, saddens, indignant, horrified, prays, asks. Poems are 
linked together in our imagination, give rise to the image of a living person, who records his every new feeling, every new event in his life. It's like a continuous autobiography, a continuous diary, a presentation of the most intimate experiences in the most true and frank way. There are no special topics here, no special sections and cycles.

Theoretically, the poetess is not delimited from the "world", but puts it on the same level with the "I" "I" and "the world", according to her plan, were to become equal support links of creativity.

It is interesting to trace the attitude of the poetess to love. Akhmatova learned in her youth the sweet poison of unrequited love, and on the other hand, love for herself, to which she could not answer. From an early age she had many admirers, but, perhaps, no one was able to cause a fire of "secret heat" in her.

Akhmatova had a striking appearance. A contemporary, poet Georgy Adamovich, who knew her from a young age, recalls: "Now, in memories of her, she is sometimes called a beauty: no, she was not a beauty. But she was more than a beauty, better than a beauty. I never had to see a woman whose face and whole appearance everywhere, among any beauties, would stand out for its expressiveness, genuine spirituality, something that immediately attracted attention. Later, a tragic shade became more distinct in her appearance ... when, standing on the stage ... it seemed, she ennobled and elevated everything that was around ... Sometimes, a person who had just been introduced to her immediately declared his love to her.

Confirmation is a poem written by a wonderful Uzbek poet, academician, and author of amazing books Aibek in memory of Anna Akhmatova:

And I, without taking my eyes off,

Looking around the far corner

Where courageously along Ankhor /

The poetry itself goes on.

So, from a young age, the image of Anna Akhmatova was born: the image of a "fatal", sad woman who, besides even her own will, without making any effort, wins men's hearts. However, it is also important to emphasize that one of the explanations for the "silent lyrical heroine" is that such an image corresponded to the ideal of a woman, which was in vogue at the time. This reflected gender specificity - a woman was only allowed to be passive. In this sense, Akhmatova perpetuates the classical and symbolist associations of women as objects, and not as creators.

Y.V. Matveeva in the article "Once again about the female consciousness of Anna Akhmatova" noted that Akhmatova taught women not only to talk about themselves, but also to respect and appreciate themselves. In other words, in Akhmatova's poetry, a rejection of the "truly feminine value series (family - love - children - home)" is clearly expressed. It is replaced by the feeling of life as a "love torture", as well as, in the words of Pasternak, the feeling of a "noble sense of equality with the world" [7, 81].

\section{V.Conclusion}

An extremely tragic consequence of this refusal can be a suicidal act committed by a lyric heroine. Take, for example, the death of the heroine of Akhmatova's poem "I don't need my legs anymore," in which, throwing herself into the water, she turned into a mermaid. Thus, having drowned, the lyrical heroine was freed from love suffering. And her lover who remains to live realizes his guilt. $\mathrm{He}$ is deeply upset by the tragedy that has taken place ("he became pale and sad-mute"). So, 
Akhmatova's unfailing love relationship makes both woman and man unhappy. The point of death, according to the researcher A.A. Chevtaev, "marks Akhmatov's idea of the fundamental drama of love relationships" [8], and he sees the cause of the tragedy in "the inherent value mismatch between masculine and feminine principles." Perhaps, Akhmatova, solving this problem through an extreme event - the suicide of the heroine, in her poems paves the way, as Nedobrovo suggested, "the path of a woman to her religious equality with a man."

Thus, the study showed that it was Akhmatova who was able to carry out "a synthesis between 'female' poetry and poetry in the exact sense of the word." In other words, Akhmatova reworked the themes and many techniques of 19th century women's poetry in the spirit of universal poetics.

\section{References:}

1. Artyukhovskaya N.I .. On the drama of the early lyrics of Anna Akhmatova // Bulletin of Moscow University, 1974. No. 4. P.17.

2. 2.Akhmatova A. Collected works in 6 vols. T. 6.P. 245.

3. Zhirmunsky V.M. Creativity of Anna Akhmatova. - L .: Nauka, 1973.p. 47.

4. 4.Kalyan K.A. Intimate lyrics by R. Kataeva and A. Akhmatova. Comparative aspect // Bulletin of the Kharkov National Pedagogical University named after G.S. Frying pans, 2016. No. 2 (57). - P.73.

5. Kislova L.S., Vetoshkina M.A. Gender code in the lyrics of Anna Akhmatova // A.A. Akhmatova: Russian and national literature: Materials of the international scientific-practical conference. September 25-26, 2019 - Yerevan: Lusabats, 2019, p. 224.

6. Mandelstam O. Army of poets // Collected works in 4 volumes / Ed. G.P. Struve and B. Filippov. - M., 1991.T.2. - P.216.

7. 7.Matveeva Y.V. Once again about the female consciousness of Anna Akhmatova. // Russian woman - 3. From cook to muse: woman in culture. - Ekaterinburg, 2000.. 81.

8. Chevtaev A.A. Plot-plot structure of lyric narrative // Narratorium. - M .: RGGU, 2012. - No. 2 (4).

9. 9.Zou L. Psychologism of Anna Akhmatova's love lyrics of the 1910s - early 1920s (origins, specificity): dis ... candidate of philological sciences - Moscow, 2020. - p. 111.

10. Tsivyan T.V. Akhmatova and music // Russian Literature, 1978. N 10 / 11.p.195.

11. 11.Eichenbaum B.M. Anna Akhmatova. Analysis experience. - M .: Direct - Media, 2014, p. 16.

12. Ehrenburg. Notes on Russian poetry. - Paris: Helios, 1913. No. 1. - p.16. 